\title{
Headmaster's Strategy to Build the Character Education of School Member in SD Muhammadiyah 1 Kudus
}

\author{
$1^{\text {st }}$ Ulin Nuha \\ Department of Elementary School, \\ Universitas Muhammadiyah Kudus \\ Kudus Jawa Tengah, Indonesia \\ ulinnuha@umkudus.ac.id
}

\author{
$2^{\text {nd }}$ Suhirno \\ Departement of Elementary School, \\ Universitas Muhammadiyah Kudus \\ Kudus Jawa Tengah, Indonesia \\ suhirnopgsd@gmail.com
}

\begin{abstract}
The cause of low educational quality in Indonesia is certainly not liberated by the strategy and leadership of a headmaster as a top leader. Headmaster has an important role to lead the school management in order to be able to work consistently with the community need and development era. Meaningfully, the headmaster extremely determines the school quality in the future. One of the efforts performed headmaster improve the education qualities and grades through the character education of school members. The purpose of this research is to describe and analyze the headmaster's strategy to construct the character education of school members in SD Muhammadiyah 1 Kudus. This research utilizes the qualitative approach with descriptive method. Data-collection techniques are conducted by interview, observation, and documentation in which the research subject is a headmaster, teacher, student, and employee in SD Muhammadiyah I Kudus. Determination of research subjects is performed by purposive sampling technique. Data analysis technique utilizes mile models and Huberman such as reduction, display, and conclusion drawing or verification data. Research result indicates that headmaster's strategy as a controller in the school to build the character education is performed by coaching form permanently in the terms of modeling, habit, and reinforcing which is kind for all school members (teacher, student, and employee). Implementation of character building in school members through school culture program in SD Muhammadiyah 1 Kudus is conducted by several activities such as pray together as opening before beginning the learning process, pray duha, dzuhur together, environment care motion etcetera.
\end{abstract}

Keyword-Headmaster's Strategy, Character Education, School Member

\section{INTRODUCTION}

Nowadays, the managerial problem of elementary school (SD) is a classical sample from managerial disorganization of our education. Continuously, it gives effect toward effort to upgrade output quality of the educational system[1]. The children's various problems as violence, anarchy, looting, deceit, disobedience of valid rule, fight between student, intolerance, using bad language, premature sexual maturity and its deviation, and self-destruction[2] become challenge and give solution on the problem especially to prepare generation of nation's children in the future.[3] According to Retno Listyarti, the Commissioner of Educational Department of KPAI on her press conference on Wednesday
(30 ${ }^{\text {th }}$ October 2019$)$ in the Jakarta, "sexual violence case in the educational institution until October 2019 reaches 17 cases by 89 children has become victim. They consist of 55 girls and 34 men. Based on KPAI data, the most doer is teacher and headmaster. They consist of sports teacher (6 people), religious teacher (1 people), art teacher (a person), computer teacher (a person), IPS teacher (a person), and class teacher (4 people). Eleven cases appear in SD level, four cases happen in SMP level (junior high school), and two cases happen SMA Level (senior high school)". The high sexual violence case in SD level is caused by the children's age in SD which the children are easy tantalized and they are afraid of threat, bad value, and don't move to next level class[4]. The reality of the deviation behavior and sexual violence case, on the educational practice in Indonesia, is the evidence that quality and grade of education have not been appropriate with achievement of national education purpose written in Undang-undang No. 202003 years about national education system chapter II, Section 3 as [5] "National education functions to increase skill and to form character and prestigious nation civilization on the framework to educate life of nation by purposed to develop the student's potential so that they become devout pious human to the one almighty God, good character, health, knowledge, cleverness, creativeness, independence, and becoming democracy citizen and, responsibility". Educated people must be wise, who can utilize their knowledge for good deeds and ultimately lead a wise life in all aspects of the family, environment, society, and state regulation. Therefore, successful education is education that can equip its members with the good character that is needed in building a respected nation-state.[6]

The other hand, the various efforts has been performed by government as it is applied character education in every educational level. However, this reality hasn't be able to be implemented well so the implementation of character education is importantly studied by every educational institution such as the study about learning interaction in the class, educating through extracurricular, making a comfortable school condition for implementation of the morality value, and even the leadership of headmaster to build character education in the school. The headmaster's performance is an effort performance and a result which can 
be attained by headmaster to implement school management to achieve educational purpose.[7] Extremely, the school can implement integrated character education by managerial system of own school, and the managerial success depends on headmaster's leadership. The headmaster's positive attitude is able to push, to direct, and to motivate all school members to cooperate on achievement of vision, mission, and school purpose.[8] This point indicates that the character education building, headmaster cooperates and collaborates with other school members such that increasing of school quality through character education building can optimally implemented preferably.

Based on description, the researcher performs a analysis study intensify related by "The headmaster's strategy to build character education for school member in SD Muhammadiyah I Kudus". The questions which are answered by this article are: 1) How the headmaster's strategy to build character education for school member in SD Muhammadiyah I Kudus? and 2) How the implementation of character education for school member?

\section{THEORY BASIC}

\section{A. The Headmaster's Strategy in the Building Character Education of School Members}

The headmaster has strategic position as authority leader in the school to implement character building and responsible on the success of school in the character education building for school member. Headmaster is core actor to push development and progress of school to increase accountability of the student's achievement and his program so that it can be achieved superiorly. Headmaster's leadership is necessarily empowered such that headmaster can have a role appropriately with his assignment, authority, and responsibility.[9] The headmaster's significant assignment is such as: teaching in the class, giving guidance to student, developing staff, following development of IPTEK, and giving sample of counseling/career.[10] The significant of headmaster's management and leadership presently gives freedom to every headmaster to emphasize and to prioritize certain competence appropriately with vision and mission of school and every region. These conditions and freedom are expected to be able to upgrade the quality of human resource (SDM), and eliminate the various problems related by educational relevance[8] meaningfully, on overcoming the sundry educational problems, the headmaster have to set of comprehension about the fact condition of school, valid policies, the effective efficient implementation strategy, and expectations of school toward educational process implemented.

Headmaster's performance can be appreciated good if the target or purpose of school is able to be achieved. These are supported by competence, attitude, and motivation from school member such as headmaster, teacher, administration employee, student, school committee, and other functionary.[11] The headmaster's strategy in the building character education of school member is a synergy which is continuity performed together by school member to build morality and character values in the school institution. The character is viewed as part of social psychology element related with around context usually observed psychological perspective.[3] According to Lickona "Character is a good objectivity over human quality, whether known to human or not. Those good qualities are asserted by society and religion in the world because those are good, and have right on our conscience.[12]

The character education approach describes that every school must have explicit morality code clearly for student.[13] It is performed so that the students and other school members can protect a good something and realize that goodness in daily life wholeheartedly.[14] In the school level, the achievement criteria of character education is formed a school culture such as tradition, daily habit, and symbols practiced by whole school member and society must base on those values,[15] will make a person have good habits of thought, feeling, and actions towards God Almighty, their individual entities, others, environment, and nation.[16] Therefore, headmaster's strategy in building character education for school member has to be aimed to create positive habit and norm in the school, the harmony relationship and collaboration based on attitude mutual respect, mutual appreciating, and mutual synergy with other school member to create quality of school in the future.

\section{RESEARCH METHOD}

Research method used in this research is qualitative research method. qualitative research method is a research method adopted to study natural object condition in which a researcher is a principle instrument.[17] This research is purposed to describe and to analyze related headmaster's strategy in building character education for school member at SD Muhammadiyah I Kudus. The determining of research subject is conducted by purposive sampling technique that is sample determining of data source by certain judgment. For example, the one considered the most knows what we expect.[18]

Therefore, the subject in this research is headmaster, teachers, students, and employees at SD Muhammadiyah I Kudus. Through these some research subjects are expected to obtain comprehensive data concerning headmaster's strategy in building character education for school member.

The technique of data collection is carried out by interview, observation, and documentation method. The first, deep interview refers to unstructured interview guide. Interview is primary data in this research aimed to get data by giving questions about anything toward informant concerning headmaster's strategy in building character education for school member. The informants interviewed are headmaster, teachers, students, and employees. Secondly, observation is carried out to obtain information concerning headmaster's strategy in building character education for school member. The observation performed is formal and no formal. Thirdly, document which is studied is texts as archives of school, vision, mission, the rule of school, an event performed by school member, and other supporting documents pointing existence of character education from school member at SD Muhammadiyah I Kudus. The data analysis of this research is Miles and Huberman Model. It is 


\section{CONCLUSION}

Based on this research result and discussion, the researcher forms some conclusion that the headmaster's strategy to build character education of school member in SD Muhammadiyah I Kudus is performed by several strategies. Firstly, exemplary action is good model for all school members. The second strategy is habit toward the various activities in the school, both religious and caring. The third strategy is reinforcing by positioning teacher as partner to build character education. Provisionally, the outstanding character value which is developed in SD Muhammadiyah I Kudus is religious and environment caring values. Based on conclusion above, the suggestions of this research include, the need of the headmaster to develop character education of school member continuity so that other positive character values can be developed through the various activities in the school. The headmaster's policy has to be followed by all school members so that there is a synergy on the implementation of policy. The significant involvement of student's parent in the character building is very expected to be able to aid developing character education in the school by more attention to character education for student in the home, and always protects and guides student's character with school collaboratively.

\section{ACKNOWLEDGMENTS}

Authors would like to thank the rector Muhammadiyah University of Kudus (Rusnoto) as well as Headmaster's SD Muhammadiyah 1 Kudus, who given me opportunity to research on the topic (Headmaster's Strategy to Build the Character Education of School Member in SD Muhammadiyah 1 Kudus), and all those who have helped the writer in finalizing of this journal.

\section{REFERENCES}

[1] H.A.R. Tilaar, Manajemen Pendidikan Nasional. Bandung: Rosdakarya, 2011.

[2] A. W. Dodd, "Educating for Character: How Our Schools Can Teach Respect and Responsibility. By Thomas Lickona. New York: Bantam Books, 1991," NASSP Bull., 1992.

[3] D. K. A, Character Education: The Strategy to Educate Children in Global Era. Jakarta: Gramedia, 2007.

[4] “Anak jadi Korban Kekerasan Seksual di Sekolah," 2019. [Online]. Available: www.KPAI.com/BankData/Anak-jadi-Korban-KekerasanSeksual-di-Sekolah. [Accessed: 15-Nov-2019].

[5] Undang-Undang RI Nomor 20 Tahun 2003 Tentang SISDIKNAS \& PPRI Tahun 2015, Undang-Undang RI Nomor 20 Tahun 2003. Bandung: Citra Umbara, 2017.

[6] M. M. dan R. P. Pane, "The Significance of Environmental Contents in Character Education for Quality of life," Soc. Behav. Sci., vol. 222, pp. 244-252, 2016.

[7] Andang, Manajemen dan Kepemimpinan Kepala Sekolah. Yogyakarta: Ar-Ruz Mediaa, 2014.

[8] E. Mulyasa, Manajemen \& Kepemimpinan Kepala Sekolah. Jakarta: Bumi Aksara, 2015.

[9] D. Purwanti, "Kepemimpinan Kepala Sekolah dalam Meningkatkan Kompetensi Guru," J. Ilm. Didakt., vol. XIV, Nomor, pp. 390-400, 2014.

[10] Jerry H. Makawimbang, Kepemimpinan Pendidikan yang Bermutu. Bandung: Alfabeta, 2012.

[11] Budi Suhardiman, Studi Pengembangan Kepala Sekolah. Jakarta: Rineka Cipta, 2012.

[12] J. W. Santrock, Educational Psychology 5th Edition. 2011.
[13] ALKHAL H; WONG R; RABIE B, "Character Matters: How to Help Our Children Develop Good Judgment, Integrity, and Other Essential Virtues," Angle Orthod., 2004.

[14] R. A. Sani, Pendidikan Karakter: Mengembangkan Karakter Anak yang Islami. Jakarta: Bumi Aksara, 2016.

[15] Jamal Ma'mur Asmani, Buku Panduan Internalisasi Pendidikan Karakter di Sekolah. Yogyakarta: Diva Press, 2013.

[16] Fathur Rokhman dkk, "Character Education for 2045 Gold Generation,” Soc. Behav. Sci., vol. 141, p. 3, 2014.

[17] Sugiyono, Memahami Penelitian Kualitatif. Bandung: Alfabeta, 2016.

[18] Sutrisno Hadi, Research Methodology. Yogyakarta: Pustaka Pelajar, 2016.

[19] A. Huberman and M. Miles, "Understanding and Validity in Qualitative Research," in The Qualitative Researcher's Companion, 2012.

[20] E. Mulyasa, Revolusi Mental dalam Pendidikan. Bandung: Remaja Rosdakarya, 2015.

[21] D. K. A, Strategi Pendidikan Karakter: Revolusi Mental dalam Lembaga Pendidikan. Yogyakarta: Kanisius, 2015. 